\title{
A PROIBIÇÃO DAS MANUFATURAS NO BRASIL E A POLÍTICA ECONÔMICA PORTUGUESA DO FIM DO SÉCULO XVIII
}

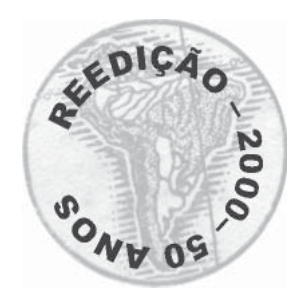

\author{
Fernando Antônio Novais
}

\section{Res U M O}

O artigo interpreta o Alvará de 1785, que proibia as manufaturas têxteis na colônia brasileira, explorando ao mesmo tempo sua lógica interna (suas incoerências e contradições teóricas) e seu contexto. Analisado de várias perspectivas e em todos os seus aspectos (econômicos, políticos e ideológicos) ilumina-se o significado histórico do documento e os motivos que lhe deram origem.

\section{A bstrac ${ }^{\dagger}$}

This article interpretes the 1785 'Alvara' by which Portugal forbade the manufacturing of textiles in Brazil. Only by exploring at the same time the internal logic of the document (its incoherences and theoretical contradictions) and its historical context is possible to understand its motives and meanings.

\section{Palavias - C have}

Sistema colonial - Política econômica - Fisiocracia - Antigo Regime.

\section{Ke y w ords}

Colonial system - Political economy - Phisiocracy - Old Regime.

\footnotetext{
* Este artigo foi publicado originariamente na Revista de História $\mathrm{n}^{\circ}$ 67, 1966, com a seguinte qualificação do autor: Instrutor da Cadeira de História da Civilização Moderna e Contemporânea da FFCL/USP. O texto foi modernizado em sua ortografia e sua Bibliografia padronizada de acordo com as Normas da Revista.
} 
0 Alvará de 5 de janeiro de 1785 , por que se proíbem nas capitanias do Brasil as manufaturas têxteis, tem sido reiteradamente tomado como a manifestação mais expressiva da persistência de uma política colonial de tipo mercantilista tradicional, por parte da Coroa portuguesa, a discrepar das tendências francamente reformistas da época das Luzes. Já Varnhagen, ao tratar do reinado de D. Maria I, no que se refere à legislação especialmente respeitante ao Brasil, menciona unicamente a referida determinação, acrescentando tratar-se do "ato mais arbitrário e opressivo da metrópole contra o Brasil desde o princípio do reinado anterior"(s/d: 374).

Na esteira de Varnhagen, refere-se Capistrano de Abreu à extinção brutal das manufaturas (1954: 335). Lemos Britto dedica-lhe todo um capítulo, onde aliás há algumas observações bastante lúcidas (1939: 191ss.). Roberto Simonsen (1957: 375) e Caio Prado Júnior (1953: 222) não discrepam deste ponto de vista. Heitor Ferreira Lima não vai além (1961: 167-170).

Não pode haver dúvida que este modo de ver tem o seu fundo de verdade, sobretudo quando são levados em conta preferentemente os efeitos do referido ato para a economia brasileira. Pode-se, porém, legitimamente observar que, ao focalizar-se desta maneira o assunto, ficam de lado outros aspectos fundamentais para se compreender o problema. É que o alvará proibitório faz parte de um conjunto maior - a política colonial portuguesa do fim do século XVIII - do qual não pode ser desvinculado se the quisermos alcançar o significado. Por sua vez, a política colonial insere-se inseparavelmente no quadro geral da política econômica portuguesa da época, em função da qual se orienta e se concretiza. Empenhados na análise da constituição, ao longo da história, da economia nacional brasileira, aqueles autores não podiam deixar de marcar nitidamente os efeitos negativos da referida proibição sobre atividades econômicas da então colônia, e suas repercussões no futuro arcabouço econômico da nação. Mas ao caracterizá-la como expressão de uma política econômica, suas análises tornam-se porventura menos exatas, dada a falta do quadro mais amplo de referências a que nos referimos; não será pois demasiado concluir que iluminam apenas uma face do fenômeno, tornando-se indispensável encará-lo de outros ângulos, para, só depois, repensar o conjunto. 
O próprio texto do famigerado alvará não tem sido examinado em profundidade. No conjunto e à primeira vista, a impressão é de argumentação frouxa, um enredo de contradições; afirmações doutrinárias colidem com determinações efetivas. Isto levou Lemos Britto, dos poucos a sondar por dentro o texto legal, a referir-se à "capciosidade" do arrazoado (1939: 197ss.). De fato, afirma-se enfaticamente que nos "frutos e produções da terra" consiste a "verdadeira e sólida riqueza", com o que se justifica não só o impedir-se o desvio de fatores de produção para os setores manufatureiros, como mesmo a supressão das manufaturas já instaladas; mas alude-se a seguir a que os produtos do Brasil são essenciais ao comércio de Portugal, que, como é sabido, em grande parte comportava a exportação de manufaturas portuguesas para a colônia. O princípio doutrinário - de base fisiocrática - metamorfoseia-se, assim, quando aplicado num ou noutro pólo do pacto colonial. Além disso, como é por demais evidente que a expansão manufatureira amplia a procura de matérias-primas - legítimos frutos e produções da terra, como por exemplo o algodão -, resulta que para incrementar a "verdadeira e sólida" riqueza é conveniente fomentar as manufaturas. Mas, replica o alvará, o Brasil é escassamente povoado, e a aplicação de braços à manufatura leva necessariamente a desfalcar-se o cultivo dos campos. Não, redargüimos nós, pois o crescimento da produção da terra pode ser potencializado com melhorias tecnológicas; e aliás, sendo como era escravista o regime de trabalho, a dificuldade se resolveria estimulando o tráfico africano, para gáudio dos mercadores ligados a esse ramo de comércio... E por aí adiante poderíamos seguir polemizando vitoriosamente com o mudo texto de lei. Mas não é evidentemente este o caminho que conduz a uma compreensão efetiva deste momento das relações do Brasil-colônia com a metrópole portuguesa ${ }^{2}$. Constatada a incoerência, o que se impõe é buscar o significado dessas contradições.

\footnotetext{
${ }^{1}$ O Alvará de 5 de janeiro de 1875 está publicado em Antônio Delgado da Silva, Collecção da Legislação Portuguesa.... vol. III, 1775-1790, Lisboa, 1828: 370; Revista do Instituto Histórico e Geográfico Brasileiro, t. X, (2ª ed. 1870: 228-230). Transcrevem-no, entre outros, Lemos Britto (1939: 195-197) e H. Ferreira Lima (1961: 311-313).

${ }^{2}$ Este é, precisamente, o erro de perspectiva em que incorre Lemos Britto, que aliás não penetrou fundo nas contradições do alvará.
} 
Restituamos, portanto, ao texto legal o seu andamento próprio. Principia-se pela afirmação de que, nas capitanias do Brasil, nos últimos anos, grande número de fábricas e manufaturas se tem difundido; o que importa, prossegue o alvará, em grave prejuízo da lavoura e mineração, pois a população é escassa, dando-se por evidente que, aumentando o número de fabricantes, diminui inevitavelmente o de cultivadores; aduzindo-se logo que diminuem também os braços para o desbravamento dos extensos domínios ainda incultos, deixando de prosperar as sesmarias, doadas aliás à condição de que se cultivem; e igualmente se prejudicam as lavras mineiras, cuja produção, aliás, ressalta o legislador, vem efetivamente diminuindo. Ora, verdadeira riqueza são os frutos da terra, que se não obtém senão pelas fainas agrícolas ou mineradoras. E para além, os produtos brasileiros são básicos ao comércio e navegação entre os vassalos de Portugal com os dos domínios americanos, os quais comércio e navegação é dever do soberano comum animar para o benefício de todos, removendo os óbices que se oponham. Em conseqüência do que, manda extinguirem-se todas as fábricas, manufaturas ou teares de galões, de tecidos ou de bordados de ouro e prata; de veludos, brilhantes, setins, tafetás, ou de qualquer outra qualidade de seda; de belbutes, chitas, bombazinas, fustões, ou de outra qualquer qualidade de fazenda de algodão, ou de linho, branca ou de cores; e de panos, baetas, droguetes, saetas, ou de outra qualquer qualidade de tecidos de lã; ou os ditos tecidos sejam fabricados de um só dos referidos gêneros, ou misturados e tecidos uns com os outros; excetuando tão somente as fazendas grossas de algodão para uso dos negros e enfardamento de fazendas. Estabelece-se que os proprietários que, dois meses depois da publicação do alvará, forem encontrados na posse das ditas manufaturas e teares, terão pena de "perdimento em tresdobro" do valor dos referidos instrumentos e das fazendas que se acharem, ficando repartida a importância entre o denunciante e os oficiais que fizerem a apreensão (metade para o denunciante, metade para os oficiais; no caso de não haver denunciante, os oficiais se apropriam da totalidade). Seguem-se as providências burocráticas para a execução da ordem: aviso às várias autoridades competentes (presidente e conselheiros do Conselho Ultramarino, presidente do Real Erário, vicerei do Brasil, governadores e capitães generais, governadores e oficiais militares, 
ministros das relações do Rio de Janeiro e Bahia, ouvidores, provedores, outros ministros, oficiais de justiça e fazendas) e a todas as pessoas do Estado do Brasil, para que cumpram e façam cumprir a determinação. Derrogam-se, para o caso, as determinações em contrário. Assinam a Rainha e Martinho de Mello e Castro, que era então o ministro e secretário de Estado da Marinha e Ultramar ${ }^{3}$.

Preliminarmente, convém assinalar o estilo arrevesado e repetitivo em que vem redigido o alvará, aliás típico desse gênero de documentos. É que se procurava ser o mais explícito possível, não deixando margem a qualquer sombra de dúvida. Por isso, não se evitam as repetições, abusando-se mesmo da sinonímia. Expressões como "fábricas, manufacturas ou teares" poderiam sugerir uma gradação, mas não parece que se possa presumir por parte do legislador qualquer preocupação classificatória. ${ }^{4} \mathrm{Da}$ mesma forma não pudemos estabelecer distinção alguma entre "permutações mercantis" e "comércio", a não ser que pela primeira expressão se designasse o escambo puro e simples. Não enveredamos, porém, pelo matagal da estilística legislativa portuguesa por motivos formais; interessa-nos, sim, opor essa excessiva explicitação com certas obscuridades do texto, pois o contraste torná-las-á mais significativas.

Com efeito, o leitor atento já terá notado, pela descrição fiel que acima reproduzimos, que a seqüência de argumentos justificativos, entra, na sua parte final, em solução de continuidade: depois de afirmar que as produções do Brasil são fundamentais para o comércio de Portugal ("permutações mercantis, navegação e comércio"), e de sobrelevar que é dever do soberano favorecer o bem comum dos vassalos de ambos os lados do Atlântico, removendo os obstáculos - passa a decretar as proibições. Ora, faltou, visivelmente, aqui, esclarecer porque as produções

\footnotetext{
${ }^{3}$ Cf. O Alvará de 5 de janeiro de 1785 , que transcrevemos ao fim deste artigo.

${ }^{4}$ Entre "fabrica" e "manufactura" a distinção não era nítida, na época, em Portugual, até porque alí se desconhecia a maquinofatura, característica específica do Sistema Fabril. Morais, na primeira edição de seu dicionário (1789) define fábrica a "casa onde se trabalha e fabrica v.g. panos, chapéus, sêdas e outras manufaturas", e manufatura "fabrica, e oficina de artefatos v.g. de lanifícios, de sedas, chapéus, panos", acrescentando que manufatura significa também "a obra feita nelas, e neste sentido é mais usual".
} 
manufatureiras do Brasil se constituíam em obstáculo ao comércio português. No texto, contudo, a afirmação permeia o arrazoado: a fabricação de manufaturas têxteis prejudica as "produções da terra", legítima riqueza; sendo as "produções" do Brasil o "fundo e a base" do comércio português que deve ser animado, removendo os entraves, - segue-se que se devem suprimir no Brasil fábricas, manufaturas e teares. Observe-se que primeiro se fala em "manufaturas" e "produções da terra"; depois, apenas em "produções" do Brasil parecendo querer excluir-se desse conjunto as manufaturas. De qualquer modo: a afirmação não se explicita, torna-se manifesta a obscuridade a contrastar com o fervor explicativo acima referido. Nem se diga que os motivos eram óbvios, pois esses textos legislativos (Cartas régias, alvarás, leis, etc.) não hesitam em dizer o óbvio, e em repeti-lo uma e várias vezes. A razão é portanto outra, e não é difícil de perceber: explicá-lo, seria romper, publicamente, aquele bem comum de todos os vassalos da coroa, "destes Reinos e daqueles Domínios", implicaria desvendar a oposição de interesses nos dois lados do sistema colonial. Por isso, o alvará não o diz explicitamente; mas o simples fato de evitar a afirmação clara não deixa de ser muito significativo. Tinha-se, não obstante, clara consciência deste contraste de interesses e as instruções de Martinho de Melo e Castro ao vice-rei (Luís de Vasconcelos e Sousa) afirmam-no peremptoriamente ${ }^{5}$ : da mesma forma que o contrabando, a produção manufatureira colonial se faz sentir nas alfândegas da metrópole, diminuindo as saídas para o Brasil. Contra essa situação reclamam o administrador da alfândega e a junta das fábricas do Reino. Esta é a contradição básica do texto, porque reflete imediatamente uma situação real: o desenvolvimento manufatureiro de Portugal não podia prescindir do mercado colonial; a colônia porém já começa a dar mostras das primeiras e frágeis tendências para desenvolvimento autônomo. Temos de partir dessa base para compreender o alvará, e depois projetá-lo no conjunto da política ultramarina portuguesa do fim do antigo regime.

\footnotetext{
${ }^{5}$ Ofício de Martinho de Mello e Castro ao Vice-Rei Luís Vasconcelos e Sousa, 5-1-1785, R.I.H.G.B., t. X: 213-224. Nota do editor: a seguir todas as vezes que se citam documentos reproduzidos pela Revista do Instituto Histórico Geográfico Brasileiro, indicar-se-á no texto, entre parêntese, apenas o número do tomo e as páginas.
} 
Reexaminemos, pois, nesta perspectiva, o conjunto do diploma legal. O seu andamento é simples: desdobra-se em três partes claramente demarcáveis, quais sejam, constatação de uma situação de fato, justificação das normas a se adotarem e determinações positivas. Esta sequiência é corrente nos textos congêneres. Aqui, contudo, pode notar-se de um lado, certa hesitação nos argumentos justificativos, um meticuloso cuidado nas afirmações altamente ponderadas; doutra parte, aquele excessivo esclarecimento no que diz respeito às proibições. No conjunto, a impressão é de insegurança na argumentação e de preocupação pela efetiva execução das proibições.

Constata-se, em primeiro lugar, que se difunde grande número de fábricas e manufaturas nas capitanias do Brasil; afirma-se mais adiante, a diminuição das extrações auríferas e diamantinas. Esta segunda asserção fundava-se, como é fácil prever, na queda da arrecadação dos quintos. E de fato, se os vários autores discrepam no difícil cálculo da produção aurífera do século XVIII, há concordância quanto à diminuição paulatina a partir do meado do século; segundo Eschwege, dos mais acatados na matéria, a arrecadação do quinto atingiu o máximo de 118 arrobas em 1754, caindo a seguir; em 1764 fora de 99, em 1774, de 75, em 1784, de 63 arrobas (Eschwege [1833] 1944, I: 366-8 e Coelho [1780] XV: 372). O mesmo não ocorria, porém, com a extração de diamantes, empreendida diretamente pela coroa desde 1772, e que mantém e mesmo incrementa o nível de produção no período que antecede o alvará (Eschwege [1833] 1944, II: 176 e Santos 1924: 254). A expansão das atividades manufatureiras no Brasil é, por seu turno, afirmada com base em informações oriundas da colônia, mas sobretudo inferida dos efeitos negativos que se fazem sentir sobre as alfândegas do reino, como indica o ministro do Ultramar no seu ofício acima referido. É na balança de comércio que se poderia com segurança aquilatar quantitativamente o fenômeno. Infelizmente, as séries conhecidas iniciam-se em 1796, e não temos conhecimento de se terem localizado as anteriores. ${ }^{6}$ De qualquer forma, outras fontes oferecem-nos pelo menos alguns indícios.

\footnotetext{
${ }^{6}$ Anteriores a 1796 conhecemos apenas as balanças referentes aos anos de 1776 e 1777, no Arquivo Histórico do Ministério de Obras Públicas, em Lisboa. Sobre as balanças, cf. Jorge de Macedo (1962: 37) , que programa estudo de conjunto sobre a matéria.
} 
Já em 1779, o relatório com que o marquês de Lavradio passou o vice-reinado ao sucessor apontava a existência de fábricas e teares em Minas; o que constitui, anota o marquês, fator negativo para o comércio com a metrópole, pois os habitantes da referida capitania iam-se tornando independentes do abastecimento da Europa (IV: 457). Martinho de Melo e Castro, no ofício que acompanha e institui o alvará de 1785, afirma por outro lado que a comprovação se tem feito na metrópole por amostras de tecidos remetidos do Brasil para a Secretaria da Marinha e Ultramar (X: 214). Quanto ao montante dos estabelecimentos e volume da produção ficava-se, pois, em meras presunções.

O que porém antes e acima de tudo se põe em relevo são os efeitos a se manifestarem no decréscimo das exportações para a colônia, o que é registrado nas alfândegas e igualmente assinalado nas reclamações da junta das fábricas de Portugal. Este o dado fundamental, ponto de partida do alvará proibitório. O intendente Pina Manique, administrador da alfândega, reivindicando medidas ao ministro Melo e Castro, no oficio que lhe dirige em 6-10-1784, lembra as "tristes circunstâncias que se podem seguir a este reino e à Fazenda de Sua Magestade" (X: 225) a não se providenciarem determinações tendentes a impedir a produção manufatureira colonial e a coibir o contrabando. É que o referido decréscimo das "permutações mercantis" registrado nas alfândegas e constatado nas fábricas portuguesas -com o conseqüente diminuendo dos direitos da coroa - decorria tanto da existência de produção brasileira de manufaturas como também e sobretudo do intenso contrabando estrangeiro e particularmente inglês que à larga se praticava nas costas do Brasil.

Este ladeamento do exclusivo colonial português no Brasil pelas grandes potências européias vinha de longa data e se avolumava nos últimos tempos ${ }^{7}$. Não pretendemos esmiuçar aqui o assunto, já tantas vezes aventado mas ainda à espera de um estudo quantitativo (Pinho 1961: 5-12). É contudo digno de nota que ao longo

\footnotetext{
${ }^{7}$ Do contrabando do pau-brasil pode dizer-se que começou antes da própria colonização. A mais recente sistematização do assunto encontra-se na História Geral da Civilização Brasileira, dirigida por Sérgio Buarque de Holanda (1960 I-I: 89-95 e 147-175).
} 
do século XVIII, apesar dos esforços da metrópole, sobretudo a partir do consulado pombalino, para por cobro a esse apoucamento da sua exploração ultramarina, o contrabando se vai incrementando, na medida mesma em que se amplia o desnível entre o desenvolvimento econômico dos países ibéricos de um lado, e de outro as potências marítimas (Inglaterra e Holanda) e França ${ }^{8}$. Sebastião José de Carvalho e Melo, que já na embaixada de Londres, formara juízo sobre o comércio inglês (Azevedo 1922: 29ss.), forcejou sempre, à frente da administração portuguesa, por impedir a penetração inglesa no ultramar; é abundante a correspondência polêmica travada pelo cônsul inglês em Lisboa (então Robert Walpole) para reduzir o rigor da fiscalização pombalina ${ }^{9}$. Por maior que tenha sido o esforço, não se pode duvidar que o contrabando tenha persistido. A própria insistência legislativa indica nesse sentido. Nem era só a Inglaterra que contrabandeava. Em 1778, no início do reinado de D. Maria I e nas vésperas de deixar o vice-reinado, oficiava o marquês de Lavradio (6-6-1778) encaminhando ao Conselho Ultramarino os autos de exame feito em várias embarcações espanholas arribadas no Rio de Janeiro; os castelhanos solicitam suprimento, contra letras passadas para Espanha; o vice-rei protela, obtemperando que as instruções aconselham flexibilidade em se tratando de barcos espanhóis, dada a possibilidade de entrar prata ${ }^{10}$. Não era portanto sem motivo que as instruções ao novo vice-rei, Luís de Vasconcelos e Sousa, consignassem para logo entre as importantes obrigações do governo um "vigilante cuidado em evitar os contrabandos", pois que são "não só a ruína dos úteis vassalos, mas os que diminuem o real patrimônio destinado à cousa pública" (XXV: 479-483). A pressão prosseguiu e mesmo intensificou-se, e em 1781 era confiscada no Rio de Janeiro a chalupa inglesa Hind, remetendo-se para Lisboa os contrabandistas; Sua Majestade, porém, informa o

\footnotetext{
8 "Collecção das Leys, e Ordens que prohibem os navios estrangeiros, assim os de guerra, como os mercantes, nos portos do Brazil”, Arquivo Histórico Ultramarino (Lisboa), códice n. 1193.

9 “Coleção Pombalina”, Biblioteca Nacional de Lisboa, códice 638; contém os autos de exames em navios ingleses mandados efetuar pelo marquês de Lavradio

${ }^{10}$ Arquivo Histórico Ultramarino (Lisboa), documentação avulsa, Rio de Janeiro, caixa de 1778.
} 
ministro dos negócios ultramarinos em carta ao vice-rei, de 30-10-1781, "atendendo a algumas justas considerações do seu real serviço", manda libertar os ingleses, devendo o barco ser guardado, consertado, e conservados em depósito os "efeitos" que conduzia e o produto dos gêneros que por ventura já se tivessem vendido ${ }^{11}$. Viviamse momentos difíceis do equilíbrio europeu, e a Inglaterra cobrava caro a sua aliança.

Tão caro, de fato, que no mais das vezes a aliança inglesa encobria para Portugal uma efetiva tutela. Nem se pode prescindir da posição britânica para compreender qualquer passo da política econômica e colonial portuguesa nos séculos XVII e XVIII. O que a corte de Lisboa tinha em mira era um equilíbrio difícil que, sem comprometer de todo a necessária aliança política, permitisse recobrar uma mais larga faixa de movimentação econômica. No caso específico do alvará proibitório das manufaturas no Brasil, porém, parece convergirem os interesses da Inglaterra e da metrópole portuguesa; os tecidos ingleses participavam do abastecimento do mercado consumidor brasileiro por duas vias: através do intermediário português, e pelo comércio ilícito de contrabando, cujas pegadas documentamos acima.

São apenas exemplos colhidos na vasta documentação impressa e manuscrita referente ao tema, para balizar a persistência do contrabando. Completa o quadro, verdadeiramente escabroso, o ofício, sem dúvida digno de nota, do cônsul inglês em Lisboa, no qual o diplomata dirige-se ao governo lusitano para informar sem rebuços o volume substancial do comércio direto que se faz da Grã-Bretanha para o Brasil: nada menos que "doze navios grandes (o menor de quinhentas a seiscentas toneladas), com artilharia proporcionada, e quarenta a cinqüenta homens de equipagem" efetuam anualmente o referido tráfico. E acrescenta, com tranqüilidade verdadeiramente britânica: "Se se duvidar deste fato, as alfândegas daquele continente mostrarão a quantidade de fazendas que ali se têm despachado; e se é necessária outra prova, eu tenho uma gazeta inglesa vinda no último paquete, que anuncia for-

\footnotetext{
${ }^{11}$ Carta de Martinho de Melo e Castro a Luís de Vasconcelos e Souza, 30 de outubro de 1781, Arquivo Histórico Ultramarino (Lisboa), códice 572, f. 106.
} 
malmente dois navios a partir para o Brasil, e antes deles tinham partido outros dois". Para arrematar, esclarece que os últimos navios aportados em Lisboa, e vindos do Brasil, trouxeram ordem para alguns negociantes enviarem, em retorno dos açúcares, moeda corrente, e não fazendas européias, "porque tem os seus armazéns cheios delas, e mais baratas que em Portugal"; e mais, no Brasil já se sugeria a formação de uma companhia para o comércio regular com a Inglaterra (X: 228). Não resta dúvida de que, do ponto de vista do sistema colonial, o informe do curioso diplomata não podia ser mais edificante. Nem é para surpreender que o ministro português do Ultramar considerasse os termos dessa correspondência consular "dignos da mais circunspecta reflexão".

Meditou-se, efetivamente, na gravidade da situação, e daí resultaram as medidas proibitivas. O mesmo ofício instrutivo encaminha ao vice-rei do Brasil dois alvarás, igualmente datados de 5 de janeiro de 1785, um proibindo as manufaturas têxteis, diligenciando o outro medidas de combate ao contrabando ${ }^{12}$. Fazem um todo, tentando solucionar uma conjuntura altamente desfavorável ao funcionamento do sistema colonial português. Distinguem-se, porém, em que, enquanto o que se refere ao comércio ilícito reafirma e reforça disposições já estabelecidas, o que diz respeito às fábricas parece enfrentar uma situação nova.

Manufaturas coloniais, descaminhos, contrabandos convergem em idênticos efeitos sobre a economia portuguesa, que, como já avançamos no primeiro passo da análise que estamos perseguindo, não podia dispensar os estímulos do mercado colonial para consolidar seu esforço industrialista. Ao determinar a supressão das manufaturas existentes no Brasil (terceira parte do Alvará), bem como ao intentar coibir a penetração de economias mais desenvolvidas no mercado ultramarino, a política colonial portuguesa reage a uma situação de fato, que deve ser encarada

\footnotetext{
${ }^{12} \mathrm{O}$ alvará de 5 de janeiro de 1785 , que providencia sobre os contrabandos e descaminhos no Brasil vem publicado em A. Delgado da Silva, Collecção de Legislação... vol. 3, 1775-1790: 371-372; em manuscrito pode ler-se no códice 311 do Arquivo Histórico Ultramarino, Lisboa, f. 20.
} 
com objetividade, mas é indiscutível que ao fazê-lo procura preservar em moldes tradicionais o funcionamento do sistema, e nesse sentido é justo falar-se em persistência de uma orientação mercantilista. As preocupações relevantemente fiscais que repontam neste conjunto de documentos (alvarás, instruções) indicam no mesmo sentido conservantista.

Resta porém analisar a segunda parte do alvará. Entre a constatação dos fatos e as regras impostas, entre a tomada de consciência dos problemas e a determinação de intervir na realidade, e estabelecendo conexão entre uma e outra, desenvolve-se o arrazoamento justificativo. O raciocínio desdobra-se como segue: primeiro, o aumento do número de fábricas e manufaturas no Brasil se faz em detrimento da lavoura e da mineração, dada a escassez da população colonial; segundo, a verdadeira riqueza são os frutos e produções da terra; terceiro, os produtos coloniais formam a base do comércio entre a metrópole e a colônia. Estes os três pontos essenciais. Entre o primeiro e o segundo passos, salientase a necessidade de povoamento e ocupação do vasto território da América portuguesa, também prejudicado pelo desvio para atividades fabris. Observe-se que a argumentação se faz inicialmente no plano prático (prejuízo da lavoura e mineração), e se encerra no mesmo plano (danos para o comércio); a formulação teórica intermediária parece pois estabelecer o contato, assegurar a passagem entre um e outro momento da argumentação, dando-lhe consistência. E isto é tanto mais importante, quanto o primeiro argumento refere-se mais especificamente à colônia, relacionando-se o terceiro mais diretamente com a metrópole. A produção manufatureira colonial, disputando mão-de-obra às atividades primárias, faz decrescer a sua agricultura e mineração; isto reflete-se negativamente no comércio metropolitano cujo volume se restringe. Ora, sendo a verdadeira riqueza as produções da terra, justifica-se a proibição das manufaturas e restabelece-se a harmonia que se ia rompendo.

O princípio teórico de inspiração fisiocrática - as produções da terra constituem a verdadeira riqueza -, formulado em sentido excessivamente lato, e habilmente aplicado, permitiu pois ao legislador português articular o seu discurso com um mínimo de consonância, pelo menos aparente . Não é difícil porém desvendar-lhe as mistificações, e já mostramos de início que o mesmo princípio se inverte ao incidir na colônia ou na 
metrópole. Se quisermos prosseguir na análise, verificaremos que o próprio enunciado se prestou a manipulações. Efetivamente, a identificação dos produtos agrícolas com a verdadeira riqueza não tem na fisiocracia o sentido exclusivo dos demais setores que aqui se lhe empresta. O conteúdo do princípio, no contexto da doutrina, situa-se no nível teórico e não no prático. A ele chegaram os fisiocratas na procura da origem do excedente econômico (produit net), problema que os mercantilistas descartavam na medida em que suas análises situavam-se preferentemente no nível da circulação. Neste plano, e considerando o comércio transação de valores desiguais (o comércio é uma forma de guerra entre as nações, dizia Colbert), a teoria mercantil simplificava o problema; o lucro, manifestação exterior do excedente, advém das transações comerciais, da circulação portanto, através de vantagens concretas obtidas em detrimento do parceiro (Hugon 1959: 103). Deslocando a análise para o sistema produtivo, e dando destarte um passo decisivo no equacionamento do problema, a fisiocracia não podia deixar de se perguntar como é possível remanescer, do processo produtor dos bens econômicos, um excedente líqüido, pois que a produção não é um última instância senão consumo de riqueza que se transfigura reaparecendo sob nova forma. Aprofundando embora o exame da questão, os fisiocratas foram contudo incapazes de ultrapassar o universo material das operações produtivas, não projetando por isso a gênese do excedente na trama das relações sociais (Roll 1956: 128ss.); encaminharam-se deste modo necessariamente para a única solução que se lhes apresentava: apenas um setor da produção - as "produções da terra" - pode gerar, graças à fertilidade da natureza, esse incremento líquiido da riqueza que é o excedente econômico. Esta só categoria das atividades econômicas merece o nome de "produtiva", todas as demais são improdutivas". Improdutivas, convém imediatamente acrescentar, mas não despiciendas (Gide e Rist 1959, I: 12ss.); importantes, porque úteis, as atividades comerciais e industriais não perdem mérito aos olhos do pensamento fisiocrático. Este, em linhas muitos gerais, o significado originário da preeminência da agricultura na teoria fisiocrática, e não é preciso mais para se convencer de que o alvará de 1785 lhe forçou o sentido.

Se importa, porém, patentear todas essas incorreções e velamentos, isto não nos desobriga do exame de outros aspectos suscitados pela presença mesma do 
pensamento fisiocrático encravado em resoluções de cunho mercantilista. Note-se, de passagem, o cuidado escrupuloso com que o legislador evitou avançar por demais o sinal, contrastando explicitamente o valor das fainas agrícolas à perniciosidade dos trabalhos manufatureiros; em vez disso, envereda mais uma vez na obscuridade, para nós muito significativa, preferindo dizer que, na colônia, os braços abandonam "estes úteis e vantajosos trabalhos", (agricultura, mineração), empregandose em outros "totalmente diferentes como são os da referidas fábricas e manufaturas". Pois não é curioso, num texto tão meticulosamente elaborado, antepor "úteis e vantajosos" a "diferentes"? Dá isto a inevitável impressão de que se procurava adaptar penosamente uma doutrina, aceita como correta, a uma situação de fato, que exigia acomodações. Doutrina e realidade econômicas parece que se não compaginavam muito à vontade no fim do antigo regime em Portugal. Embora distorcida e estrategicamente utilizada, o mero aparecimento da teoria fisiocrática no próprio alvará proibitório não atesta menos o conhecimento e difusão em Portugal de uma doutrina crítica do mercantilismo tradicional, e a sua influência nas esferas governamentais. As violências e ajustamentos a que a doutrina é submetida em nosso texto não deixam por outro lado de exemplificar significativamente as vicissitudes e contradições em que a inteligência portuguesa do fim de setecentos procura equacionar, com as ferramentas mentais em voga, os difíceis problemas econômicos e sociais da metrópole e do ultramar, no quadro da aguda competição internacional.

Exemplo desse esforço e dessas contradições podem ser consideradas as várias memórias e escritos que à época se produziram sobre as minas, sua utilidade ou desvantagem, os efeitos estimulantes ou regressivos da mineração sobre o conjunto da economia nacional, as técnicas mineradoras, etc. Realmente, o legislador metropolitano, ao situar no mesmo plano de importância - como produções de terra, e pois legítima riqueza - agricultura e lavra mineira, toma posição num debate aberto no pensamento fisiocrático. E de fato, hesitaram os fisiocratas em atribuir às atividades extrativas aquela mesma capacidade de engendrar incrementos líqüidos de riqueza; não lhes escapava, contudo, a visão de que, enquanto a terra, na produção agrícola, se apresenta como uma fonte que constantemente se renova, as minas 
tendem pelo contrário a um inexorável esgotamento: na palavra de Turgot, a terra produz frutos, a mina é ela própria o fruto a recolher (apud Gide e Rist 1959: 1516). Faltou, sim observar que a agricultura é também, no fundo, uma espécie de mineração, pois igualmente tende a longo prazo a exaurir a produtividade da terra; mas isto os levaria a embrenhar-se num labirinto sem esperança para a sua doutrina, visto que a técnica e os ingredientes com que é possível manter e mesmo elevar a fertilidade dos terrenos agrícolas fazem parte do consumo produtivo, e pois não se podem considerar como saída para a explicação fisiocrática da gênese do excedente.

De qualquer forma, nesse clima de elaboração e consolidação do pensamento fisiocrático, e para mais em face do espetáculo de atraso econômico das nações possuidoras de minas sobretudo a Espanha - era natural que as explorações mineiras fossem encaradas de modo desfavorável. Já em 1748, Montesquieu, no capítulo XXII, livro XXI do Espírito das Leis, afirmava serem o ouro e a prata "uma riqueza de ficção e de símbolo", acrescentando que "quanto mais se multiplicam, mais perdem seu preço, porque representam menos coisas". Ora, essa mesma elevação dos preços provocada pelo crescimento do montante de metais nobres acresce o custo de sua exploração, resultando assim desvantajosa para o país minerador. Assim se compreenderia a decadência de Espanha. As novas idéias econômicas difundidas pela escola fisiocrática, cuja teoria implicava numa crítica ao mercantilismo, e particularmente à sua idéia metalista, consolidaram esta maneira de encarar a exploração das minas.

É claro que nos países ibéricos detentores das minas auríferas e argentíferas da América, esta visão porventura demasiado teórica do problema, havia de ser repensada na procura de redefinições mais ajustadas à sua realidade econômica. Em Portugal o assunto foi com certeza debatido, e em 1789 Rodrigo de Sousa Coutinho, futuro ministro do Ultramar, apresentou à Academia Real das Ciências memória realmente notável pelo rigor do raciocínio e largueza de vistas em que procura confutar as versões correntes ${ }^{13}$. Sua idéia central é a de que os efeitos da mineração

\footnotetext{
13 "Discurso sobre a verdadeira influência das minas de metais preciosos na indústria das nações que as possuem..." Memórias Economicas da Academia Real das Sciencias de Lisboa, Lisboa, 1789, v. I: 237.
} 
sobre a economia do país minerador condicionam-se exatamente à maneira como a atividade mineradora se relaciona com os demais setores, ou em outros termos não se pode isolar este único segmento da atividade econômica. Assim, se é certo que o surto mineiro pode provocar despovoação e desfalque de mão-de-obra em outros setores, não é menos verdade que provoca uma procura crescente de produtos de consumo, estimulando assim o conjunto da economia; em termos mais concretos, podem as minas estimular as manufaturas da metrópole, funcionando da mesma maneira que uma balança favorável. O argumento de Montesquieu, acrescenta, só é pertinente no caso de o país ser desprovido de manufaturas, e ter que cobrir a sua balança desfavorável de comércio com exportação do metal nobre. Mas isto não é pois um efeito intrínseco da mineração, e sim das condições gerais da economia. Esta era, aliás, em grande parte a situação de Portugal no século XVIII, e daí o esforço industrialista. Resulta, pois, mas isto já não está na dissertação de Rodrigo de Sousa Coutinho, que inclusive para poder vantajosamente explorar as minas do Brasil era imprescindível a metrópole portuguesa promover o seu desenvolvimento manufatureiro. A exploração da colônia americana, portanto, ao mesmo tempo, é condição de mudança na economia portuguesa, e a pressupõe. Tal o nível de vinculação e dependência, que exigia que a política econômica fosse coordenada visando um e outro setor dos domínios de el-rei Fidelíssimo.

Mais para o fim do século, Antônio Pires da Silva Pontes Leme volta ao tema, para refutar um verbete da famosa Encyclopédie em que se afirmava sem mais ambages que "quanto fôr maior a massa de ouro na Europa tanto mais Portugal será pobre, tanto mais tempo será êle uma província da Inglaterra". ${ }^{14}$ Fá-lo porém sem o brilho e a segurança do antecessor, pois o que na realidade apresenta são as vantagens da economia monetária sobre a economia natural, o que aliás não estava em

\footnotetext{
14 "Memória sobre a utilidade pública de se extrair o ouro das minas", Revista do Arquivo Público Mineiro, v. I, 1896: 417-426. Veja-se também a "Censura" à referida memória, pelo Visconde da Lapa, Academia das Ciências de Lisboa, "Mem. Phys. e Econ.”, I, n. 2.
} 
jogo. Vale-se porém do ensejo para lembrar a "pouca utilidade das fábricas de minerar para seus donos", apontando as dificuldades da produção mineira no Brasil, terminando enfim por lembrar que se deve promover os outros setores da atividade econômica na Capitania das Minas. Em 1804 retoma o assunto Azeredo Coutinho, voltando aliás aos argumentos de Montesquieu ${ }^{15}$. Tudo isto ilustra o quadro das idéias no qual se elabora a política econômica e colonial na época do absolutismo ilustrado.

A proibição das manufaturas brasileiras insere-se neste contexto, e o alvará que lhe deu forma legal o indica concretamente, nos descaminhos de seu arrazoado e nas contradições de seu substrato teórico. Para compreendê-lo como expressão de uma política econômica, é neste quadro que deve ser situado, partindo das condições concretas em que se processava a vida econômica da metrópole e das colônias, a que já nos referimos atrás e que teremos de retomar ainda uma vez mais adiante. Ao estabelecer, por exemplo, uma como que fatal alternativa entre as atividades primárias e os labores industriais no domínio ultramarino, pode o alvará ser teoricamente criticado, e já o fizemos no início de nossa exposição. Mas se considerarmos, agora, que desenvolvimento tecnológico é bloqueado numa economia escravista (Williams 1944: 6-7), que, doutra parte, não se pode avolumar indefinidamente o contingente de escravos no sistema sem romper um mínimo de equilíbrio indispensável (é de se registrar aqui que as exceções que se abrem nas proibições ajustam-se às exigências da economia escravista); e se ponderarmos, ainda, que, nas condições específicas da economia colonial de baixo nível de capitalização, o empresário dificilmente poderia cometer ao mesmo tempo tarefas agrícolas e manufatureiras - acrescendo para mais que a atividade agrícola visada é em parte, como salienta o próprio alvará, desbravamento e ocupação de novas áreas - aquelas asserções do texto legal começam a fazer sentido. Anote-se, ademais, que a questão desse "equilíbrio" nas atividades econômicas se colocava também nas relações entre as

\footnotetext{
15 J. J. da Cunha de Azeredo Coutinho, "Discurso sobre o estado atual das minas do Brasil" (1966: 187-229).
} 
lavras mineiras e os trabalhos agrícolas, e um escritor da época reclamava exatamente que se estimulasse, nas Minas Gerais, a agricultura, pois a obsessão mineradora provoca graves problemas na capitania ${ }^{16}$. Poder-se-ia, contudo, insistir ainda em que, promovendo a economia colonial a capitalização na metrópole em detrimento da colônia, seria possível canalizar de volta esses capitais para o ultramar... E o argumento teria sem dúvida um sabor utópico, quando projetado na época em que esses fatos se passaram, mas de qualquer forma, nas circunstâncias concretas que estamos analisando, nem essa capitalização metropolitana era intensa em Portugal, e os recursos ali estavam sendo dificultosamente mobilizados para o esforço de industrialização. Ora, exatamente este esforço pelo desenvolvimento manufatureiro em Portugal esbarrava em obstáculos institucionais, em cuja remoção se mobilizavam as novas linhas de pensamento crítico do antigo regime (fisiocracia, economia clássica inglesa, filosofia da Ilustração). Assim é que o pensamento fisiocrático insinua-se no alvará de 1785 , o qual, se lhe restituímos antes o andamento próprio, readquire agora a sua particular coerência.

Se esta tentativa de situar o discutido alvará no quadro mental de sua época e em fase das condições concretas sobre as quais devia atuar, ajuda-nos a compreender os motivos que lhe deram origem, e a forma que assumiu, completará o nosso esforço para apreender o seu significado o exame da sua aplicação e dos seus efeitos. Não é para supor que o impacto da proibição sobre a economia colonial brasileira tenha assumido dimensões de grande monta. É impossível perder de vista, quando se pretende encarar a atuação efetiva da resolução legal, que a estrutura econômica do Brasil colônia era de todo desfavorável ao desenvolvimento das manufaturas. De fato, o regime escravista, base sobre que repousa todo o sistema, limita substancialmente as possibilidades de constituição de um mercado interno, pressuposto

\footnotetext{
16 "Considerações sobre as duas classes mais importantes de povoadores da capitania de Minas Gerais, como são as de mineiros e agricultores...” (R.I.H.G.B., XXV: 421-429). Caio Prado Jr. (1953: 161) supõe ser José Vieira Couto o autor, e a suposição se confirma quando observamos que as referidas "considerações" fazem parte da segunda memória sobre a capitania de Minas (1801) desse autor, publicada na Revista do Arquivo Público Mineiro, v. XXV, 1898: 70.
} 
indispensável da expansão industrial. Propícia era, de fato, esta situação para o florescimento de um artesanato doméstico de tecidos grosseiros para escravos ou mesmo para as camadas livres inaptas para a aquisição dos artigos importados. Mas isso, exatamente, é o que se permitia no alvará.

Os dados de que dispomos sobre a aplicação do alvará sugerem indubitavelmente que pouca coisa se encontrou para apreender. Na capital da então colônia, que era, juntamente com Salvador, das maiores aglomerações urbanas da América portuguesa na época, e pois onde melhores condições havia para as atividades manufatureiras, - o vice-rei Luís de Vasconcelos e Sousa tratou de executar as ordens régias com as devidas cautelas recomendadas nas instruções (Azevedo 1956: 51). Diga-se de passagem, não se deu muita pressa nessa tarefa; o ofício em que dá conta do cumprimento das determinações metropolitanas data de 12 de julho de 1788 . Isto aliás exemplifica bem a morosidade da administração colonial. Realizadas as buscas e feitas as apreensões, o resultado foi visivelmente decepcionante: reuniram-se ao todo para remeter à metrópole 13 teares de tecidos de ouro e prata. E note-se que a sua distribuição mostra o caráter artesanal das atividades: Jacob Munier possuía 5 teares, dos quais um desarmado; José Antônio Lisboa, 3 teares; Sebastião Marques, 3 teares - sendo que um desarmado; Miguel Xavier de Morais, 1 tear; José Maria Xavier, 1 tear. A rigor, não se pode pois falar em fábricas ou manufaturas empresarialmente organizadas. Talvez somente no primeiro caso, e com algum esforço, possa admitirse a classificação, e é sintomático o nome estrangeiro do empreendedor. De teares de lã, linho ou algodão há referências vagas não quantificadas: de João Monteiro Celi afirma-se que possui "teares de grosserias de algodão em que algumas vezes fabricava uns cobertores felpudos de algodão fino, e panos grossos ou baetões do mesmo algodão"; de José Luís, José Francisco, Antônio José, Antônio de Oliveira do Amaral, Maria da Esperança, Francisco de São José; Custódio José, Manuel de Morais, Maria Antônia, Ana Maria, diz-se que têm "teares da mesma qualidade de grosseria de algodão, nos quais algumas vezes fabricavam toalhas de mesas e guardanapos". E foi tudo quanto se encontrou. Remetendo para Lisboa estas informações, acrescentava o vice-rei ter transmitido as ordens da Rainha aos governadores das 
capitanias subalternas do Rio Grande e de Santa Catarina, bem como ao ouvidor da comarca dos Campos de Goitacazes para que se tomassem as necessárias providências; mas já adiantava estar contudo persuadido de que "os teares que nelas podem existir são próprios para as (manufaturas) permitidas e toleradas" (X: 230-240).

Para as demais capitanias seguiram idênticas instruções, mas é legítimo presumir que os resultados não tenham sido diferentes. Não conhecemos as apreensões realizadas em Minas Gerais. Nos seqüestros da Inconfidência figuram apenas: "um tear preparado em tudo", três "rodas de pau de fiar", uma "fieira de ferro" e um "banco grande com roda de puxar fieira" ". É preciosa todavia a observação de José Vieira Couto, sempre bem informado a respeito de sua capitania natal, em que afirma que "nunca em Minas se fabricara senão teçume próprio para os escravos e gente miúda” (XXV: 425).

Também o governador da capitania de São Paulo recebeu a ordem proibitória e as instruções, sendo o oficio com que se encaminharam os documentos legais datado de 3 de fevereiro de $1788^{18}$. Mais uma vez, aqui, o combate ao contrabando aparece ligado à supressão das manufaturas. Feitas as averiguações, oficiava Bernardo José de Lorena em 16 de outubro de 1788 ao ministro Martinho de Melo e Castro para esclarecer não possuir "notícias de fábricas de qualidade alguma das proibidas", concluindo, como para encerrar o assunto, que "com este oficio tenho respondido a todos que de V. Excia. tenho até agora recebido", mente a existência de produção têxtil do tipo permitido.

As palavras do Vice-Rei Luís de Vasconcelos bem como as expressões do governador Bernardo de Lorena são muito esclarecedoras, e comprovam o que antes dissemos: as condições da economia colonial escravista, com seu estreito mercado interno, se eram desfavoráveis ao desenvolvimento de atividades propriamente manufatureiras competitivas com as importações européias, eram por outro lado alta-

\footnotetext{
${ }^{17}$ Autos de Devassa da Inconfidência Mineira, Rio de Janeiro, 1936, V: 238, 455, 482; VI: 84 e 89.

${ }^{18}$ Documentos Interessantes, XXV, 1898: 70.

${ }^{19}$ Id.: XLV: 18.
} 
mente estimulantes para o florescimento de uma produção têxtil ao nível artesanal e doméstico, visando sobretudo o consumo dos escravos. Essas atividades podiam mesmo adquirir um certo volume, sobretudo nos momentos em que - como no fim do século XVIII - as condições do setor exportador eram prósperas, e dentro das unidades produtivas ligadas ao mercado externo todos os fatores se mobilizavam na produção das mercadorias exportáveis. Às áreas de economia de subsistência, abria-se então a possibilidade de uma produção que transcendia o consumo local, abastecendo o setor exportador; assim se estabelecia uma circulação interna dos tecidos grosseiros. De fato, as pesquisas e reflexões de Sérgio Buarque de Holanda (1957: 251ss.), relativas às antigas técnicas de produção no Brasil permitiram reconstruir o quadro da antiga produção artesanal e doméstica de tecidos na capitania de São Paulo, e suas pulsações ao longo do tempo. Como fica amplamente documentado no referido trabalho, remontam ao século XVI essas atividades; intensificaram-se no século seguinte, acompanhando a difusão dos algodoais e dos rebanhos e ovelhas, destinando-se os produtos sobretudo a vestir escravos e índios administrados; no fim do século XVII e começo do XVIII esses tecidos já eram vendidos em outras áreas. A emigração para as minas, e sobretudo, no fim do século, a integração da capitania de São Paulo na economia exportadora através da produção açucareira, fez diminuir os braços para aquelas atividades tradicionais. É sobre esta situação que incide o alvará de 1785, e a sua atuação não podia deixar de ser muito restrita.

Todas essas considerações reduzem em grande parte a visão, que tantos autores apresentam, dos efeitos das medidas proibitivas emanadas da corte portuguesa. É mesmo de se considerar que os estadistas da metrópole andavam porventura pouco informados das condições da economia colonial, ao baixarem as proibições; porém não se pode, como já indicamos acima, separar os dois alvarás (manufaturas e contrabandos) - e ambos visavam resguardar condições para o incremento da indústria metropolitana portuguesa. Na realidade, esta achava-se muito mais ameaçada pela penetração das economias européias mais avançadas do que pelas possibilidades de desenvolvimento manufatureiro da colônia. A proibição das manufaturas no Brasil era uma medida que tinha a seu favor as tendências estruturais 
ainda persistentes na economia colonial brasileira. A contenção do comércio de contrabando, pelo contrário, enfrentava os impulsos mais vigorosos do capitalismo industrial nascente, e por isso foi incapaz de concretizar o seu desiderato. O comércio ilegítimo prossegue crescente para o fim do século, rompendo enfim as barreiras com a abertura dos portos ${ }^{20}$. Situação interna e condições internacionais entrelaçavamse, porém, por outras vias. O pensamento reformista, crítico do antigo regime, que como vimos em Portugal se procurava integrar num esforço de reequacionamento da realidade, atingia a colônia nas suas formas mais avançadas e já não reformistas; e assim o surto manufatureiro encarnando possibilidades, embora precárias, de desenvolvimento autônomo da economia brasileira, poderia servir de suporte material às idéias separatistas (X: 218). Abrir caminho neste emaranhado de contradições era a tarefa nada fácil dos dirigentes metropolitanos; e é levando em conta todos esses aspectos econômicos, políticos e ideológicos que se pode compreender o alvará de 1785, que, analisado em todas as suas partes e de várias perspectivas, reaparece agora, no seu verdadeiro sentido histórico, espelho e produto de seu tempo.

\footnotetext{
${ }^{20}$ Ao chegar à Bahia, nas vésperas da abertura dos portos, o Príncipe Regente D. João tem ainda que mandar apreender um brigue que contrabandeava tranquiilamente pau-brasil (Pinho 1961: 8).
} 


\section{Alvará de 5 de janeiro de 1785}

Eu a Rainha faço saber aos que este Alvará virem: Que sendo-me presente o grande número de Fábricas, e Manufacturas, que de alguns annos a esta parte se tem diffundido em differentes Capitanías do Brasil, com grave prejuizo da Cultura, e da Lavoura, e da exploração das Terras Mineraes daquelle vasto Continente; porque havendo nelle huma grande, e conhecida falta de População, he evidente, que quanto mais se multiplicar o número dos Fabricantes, mais diminuirá o dos Cultivadores; e menos Braços haverá, que se possão empregar no descubrimento, e rompimento de huma grande parte daquelles extensos Domínios, que ainda se acha inculta, e desconhecida: Nem as Sesmarias, que formão outra consideravel parte dos mesmos Dominios, poderão prosperar, nem florecer por falta do beneficio da Cultura, não obstante ser esta a essencialissima Condição, com que forão dadas aos Proprietarios dellas: E até nas mesmas Terras Mineraes ficará cessanda de todo, como já tem consideravelmente diminuido a extracção do Ouro, e Diamantes, tudo procedido da falta de Braços, que devendo empregar-se nestes uteis, e vantajosos trabalhos, ao contrario os deixão, e abondonão, occupando se em outros totalmente differentes, como são os da referidas Fabricas, e Manufacturas: E consistindo a verdadeira, e sólida riqueza nos Frutos, e Producções da Terra, as quaes sómente se conseguem por meio de Colonos, e Cultivadores, e não de Artistas, e Fabricantes: e sendo além disto as Producções do Brasil as que fazem todo o fundo, e base, não só das Permutações Mercantis, mas na Navegação, e do Comercio entre os Meus Leaes Vassallos Habitantes destes Reinos, e daquelles Dominios, que devo animar, e sustentar em commum beneficio de huns, e outros, removendo na sua origem os obstaculos, que lhe são prejudiciaes, e nocivos: Em consideração de tudo o referido: Hei por bem Ordenar, que todas as Fabricas, Manufacturas, ou Teares de Galões, de Tecidos, ou de Bordados de Ouro, e Prata: De Velludos, Brilhantes, Setins, Tafetás, ou de outra qualquer qualidade de Seda: De Belbutes, Chitas, Bombazinas, Fustões, ou de outra qualquer qualidade de Fazenda de Algodão, ou de Linho, branca, ou de cores: E de Pannos, Baetas, Droquetes, Saetas, ou de outra qualquer qualidade de Tecidos de Lã, ou os ditos Tecidos sejão fabricados de hum só dos referidos Generos, ou misturados, e tecidos huns com os outros; exceptuando tão sómente aquelles dos ditos Teares, e Manufacturas, em que se técem, ou manufacturão Fazendas grossas de Algodão, que servem para o uso, e vestuario dos Negros, para enfardar, e empacotar Fazendas, e para outros Ministerios semelhantes; todas as mais sejão extinctas, e abolidas em qualquer parte onde se acharem nos Meus Dominios do Brasil, debaixo da Pena do perdimento, em tresdobro, do valor de cada huma das ditas Manufacturas, ou Teares, e das Fazendas, que nellas, ou nelles houver, e que se acharem existentes, dous mezes depois da publicação deste; repartindo-se a dita Condemnação metade a favor do Denunciante, se o houver, e a outra metade pelos Officiaes, que fizerem a Deligencia; e não havendo Denunciante, tudo pertencerá aos mesmos Officiaes. 
Pelo que: Mando ao Presidente, e Conselheiros do Conselho Ultramarino; Presidente do Meu Real Erario; Vice-Rei do Estado do Brazil; Governadores, e Capitães Generaes, e mais Governadores, e Officiaes Militares do mesmo Estado; Ministros das Relações do Rio de Janeiro, e Bahia; Ouvidores, Provedores, e outros Ministros, Officiaes de Justiça, e Fazenda, e mais Pessoas do referido Estado, cumprão, e guardem, e fação inteiramente cumprir, e guardar este Meu Alvará como nelle se contém, sem embargo de quaesquer Leis, ou Disposições em contrario, as quaes Hei por derogadas, para este effeito sómente ficando aliás sempre em seu vigor. Dado no Palacio de Nossa Senhora da Ajuda, em 5 de Janeiro de 1785 - Com a Assignatura da Rainha, e a do Ministro.

\section{Referências Bibliográficas}

ABREU, Capistrano de. Capítulos de História Colonial. $4^{\text {a }}$ ed. Rio de Janeiro, 1954.

AZEVEDO, J. Lúcio de. O Marquês de Pombal e a sua época. $2^{\text {a }}$ ed. Lisboa, 1922.

AZEVEDO, Haroldo de. Vilas e cidades do Brasil colonial. São Paulo, 1956.

BRITTO, Lemos. Pontos de partida para a história econômica do Brasil. $2^{\mathrm{a}}$ ed., São Paulo, 1939.

COELHO, J. J. Teixeira. "Instruções para o governo da Capitania de Minas Gerais" [1780], Revista do Instituto Histórico Geográfico Brasileiro, t. XV.

ESCHWEGE, L. Von. Pluto Brasiliensis [1883]. São Paulo, 1944.

GIDE, Ch. e RIST, Ch. Histoire des doctrines économiques. $7^{\mathrm{a}}$ ed. Paris, 1959.

HOLANDA, Sérgio Buarque de. Caminhos e Fronteiras. Rio de Janeiro, 1957. História Geral da Civilização Brasileira, 1960, t. I. Obras Econômicas de J. J. da Cunha de Azeredo Coutinho. São Paulo, 1966.

HUGON, Paul. História das Doutrinas Econômicas. 6 a ed. São Paulo, 1959.

LIMA, Heitor Ferreira. Formação industrial do Brasil. Rio de Janeiro, 1961.

MACEDO, Jorge de. O Bloqueio Continental, economia e guerra peninsular. Lisboa, 1962.

PINHO, Wanderley. A abertura dos portos. Salvador, 1961. 
PRADO JR. Caio. Formação do Brasil Contemporâneo. $4^{\text {a }}$ ed. São Paulo, 1953.

ROLL, Eric. History of Economic Thought. $6^{\text {a }}$ ed. Londres, 1956.

SANTOS, Joaquim Felício dos. Memórias do Distrito Diamantino. $2^{\text {a }}$ ed. Rio de Janeiro, 1924.

SIMONSEN, Roberto. História econômica do Brasil (1500/1820). $3^{\mathrm{a}}$ ed. São Paulo.

VARNHAGEN, F. A. História Geral do Brasil. $3^{\mathrm{a}}$ ed., São Paulo, s/d.

WILLIAMS, Eric. Capitalism and Slavery. Richmond, 1944. 